\title{
Theodor Adorno and the Freudian Revisionism
} Theodor Adorno e o revisionismo freudiano

Verlaine Freitas ${ }^{1}$

\begin{abstract}
The purpose of the text is to present an interpretation of Theodor Adorno's critical reading of authors considered revisionists of Sigmund Freud's psychoanalytic theory, particularly Karen Horney. We discuss critically Adorno's favorable positioning to the Freudian conception of the individual psychic nucleus in contrast to the hasty sociologization of psychoanalysis practiced by the revisionism of Karen Horney. In the final part we try to show how the Adornian perspective ends up by making, in his own way, the same mistake of a hasty sociologization of psychoanalysis he imputed to the revisionists and advocates an theoretical emphasis on the sociological realm that seems also problematic.
\end{abstract}

Key-words: Theodor Adorno; Sigmund Freud; Karen Horney; Psychoanalysis

Resumo: O objetivo do texto é apresentar uma interpretação da leitura crítica de Theodor Adorno sobre autores considerados revisionistas da teoria psicanalítica de Sigmund Freud, particularmente Karen Horney. Discutimos criticamente o posicionamento favorável de Adorno à concepção freudiana do núcleo individual do psiquismo em contraste com a apressada sociologização da psicanálise praticada pelo revisionismo de Karen Horney. Ao final, porém, procuramos mostrar como a perspectiva adorniana termina por incorrer, a seu modo, no mesmo equívoco de sociologização apressada da psicanálise imputado por ele aos revisionistas, além de defender uma ênfase teórica no plano sociológico que nos parece também problemática.

Palavras-chave: Theodor Adorno; Sigmund Freud; Karen Horney; Psicanálise

Adorno's approach to psychoanalysis has two aspects: the first one, more expressive and also more productive, is his appropriation of Freudian theory in the constitution of a social philosophy, particularly interested in the relation between individual and collectivity. The second one, ambiguous and problematic in several respects, is constituted by the readings and direct critiques of hypotheses, themes and concepts not only of Freud but of other theorists and psychoanalysts as well ${ }^{2}$. From his

\footnotetext{
${ }^{1}$ Ph.D. Philosophy, Titular Professor in the Department of Philosophy at UFMG, Belo Horizonte, Minas Gerais, Brazil. <verlainefreitas@gmail.com>

${ }^{2}$ Other commentators also divide Adorno's approach according this perspective; cf. Richard Klein, "Gemischte Gefühle. Adomo, die kritische Theorie und die psychoanalytische Praxis" and Christine Kirchhoff, "Übertreibungen. Adornos Kritik psychoanalytischer Theorie und Praxis". (Cf. "References” for details of the publications.)
} 
habilitation thesis, written between 1924 and 1927, whose third chapter makes an application of concepts from Hans Cornelius's transcendental psychology to Freudian theory, ${ }^{3}$ until his last great work, the Negative Dialectic, Adorno welcomed psychoanalytical concepts as significant elements of his philosophy - even to the point of being criticized for having a psychologist position, as in his conception of the origins of antiSemitism ${ }^{4}-$, but on the other hand he also made a harsh criticism to what he considered regressive and conformist in psychoanalytic practice. ${ }^{5}$ Instead of presenting a general exposition of relevant moments of this big panorama, I would like to make a critical comment on the text "The revised Psychoanalysis," ["Die revidierte Psychoanalyse"] whose argument is relevant for witnessing Adorno's effort to defend certain more "radical" positions of Freud, but also for demonstrating some problems in the way Adorno reads the meaning of the unconscious nucleus of the psyche. ${ }^{6}$

Adorno's text "The revised psychoanalysis" confronts two types of problems found by the revisionists in Freud's work: the ahistorical dimension of the unconscious and the interpretation of social realm by means of the theory of drives, conceived by Freud, according to Karen Horney, only as biologically determined impulses. Instead of a supposedly polarized contrast between the individual biological dimension and the

\footnotetext{
${ }^{3}$ Hans-Ernst Schiller makes a good presentation of the reading of psychoanalysis in Adorno's first habilitation thesis; cf. Freud-Kritik von links, pp.216-21.

${ }^{4}$ Cf. Konstantino Rantis, Psychoanalyse und 'Dialektik der Aufklärung', p.127. Adorno defended himself from this criticism by saying: "Those of you acquainted with the thought I advocate will know that I have no psychologism at all. Anti-Semitism should not be reduced to a psychological issue. If we assume, however, that it largely goes back to early childhood experiences - or at least that the grounds for the receptivity of individuals to anti-Semitic stimuli are established at that time of life - then the reference to the psychological aspect will be inevitable". "Zur Bekämpfung des Antisemitismus heute”, p.371.

${ }^{5}$ For a synthetic approach to Freud's presence in Adorno's thought, cf. Helmut Dahmer, "Adorno's view of psychoanalysis".

6 "The revised psychoanalysis" will be the main text of our approach. Others, such as Minima Moralia and "Zum Verhältnis von Soziologie und Psychologie”, will support our central interpretative hypotheses.

It is necessary to keep in mind that I do not intend to discuss Adorno's general position on psychoanalysis, but rather to focus his analysis on Karen Horney's revisionism and particularly the question of the link between the psychic nucleus of subjectivity and the social realm. The approach of other aspects of this theme would make the article much larger or would result in a more superficial approach to the themes discussed here. I do not claim that the problems pointed out throughout the text reflect Adorno's reading of Freud as a whole, for there are innumerable other facets, some of which receive my concordance and others not. Despite this caveat, I believe that the critical points raised here have repercussions on other writings of Adorno, even if modified. My commentary on a section of Minima Moralia at the end aims to demonstrate this, even if it is not a definitive statement, because it would be necessary to focus and discuss more passages of this and other texts of the author.
} 
network of factors and forces assimilated by individuals in their family and social relations in general, revisionism constructs a reading that more emphatically takes into account the qualitative differences between the social influences that determine the personality, neurotic symptoms, character, as well as cultural forms.

Adorno's critique, particularly directed to Karen Horney's theory set forth in New Ways in Psychoanalysis, recognizes the legitimacy of her objection to certain immediate applications of hypotheses and concepts, such as the Oedipus complex, when Freud interprets individuals as well as works of art. Despite this first positive approximation, the philosopher will question how much the supposed pluralistic realism of the revisionist reading would be truer than that the polarity seen as extreme in Freudian theory. Paradoxically, the alleged misunderstanding in contrasting the individual and solipsistic roots of the unconscious and the plane of social forces will be seen as the index of a historical truth about how each individual becomes a concrete subject in the current state of socialization processes.

\section{a. The explanatory fragility of pluralist revisionist realism}

The Freudian concept most attacked by Karen Horney is that of the drives [Triebe], because everything seems to be explained from them, which would be formed through social influences and factors. In her text New Ways in Psychoanalysis (NWP), she highlights passages in which Freud demonstrates, in fact, a propensity to conceive of the drive-scope in a biological way, and attributes him a mechanistic thought, considering his alleged disregard of the social and historical dimension of those impulses (NWP 41). Although such a concept (of the drives) is employed for a critical analysis of both personality and cultural works, it would itself fall outside the scope of the critical stand, being located in the deeper foundation of the psyche, and from there it is seen as influencing, in successive repetitions, everything else in the lives of individuals. Instead of the supposedly biological drives, Horney emphasizes character traits and certain general dispositions, such as the striving for safety and satisfaction, all of them conceived in vigilant connection with what is concretely seen and perceived in the actual circumstances of life to be analyzed (NWP 62 passim). 
Adorno's first criticism already clarifies the remainder of his argument: what the revisionists criticize in Freud is done by themselves. If Freud hypostatized a supposedly biological concept of drives without criticizing their internal dynamics of formation, ${ }^{7}$ the revisionists take up uncritically character traits and general dispositions as if they were something given, pre-established, without subjecting them to the same criticism employed to the theory of drives. The ego in Freud was conceived from an intricate relation of the drives and their vicissitudes, having a formative dynamic whose enlightenment was a task of analysis. This same psychic instance in the revisionists, in turn, is taken as unenlightened as they see the Freudian conception of the instinctual root of the ego, that is, as something mechanically determined, without specific elucidation. This means that the revisionists at least lost sight of the process of ego formation, disconnecting it from its unconscious and instinctual foundation.

Instead of deriving from the libido, the ego becomes the source of what has replaced the psychic drive energy, namely, emotional impetus, impulses, needs or passions. This means conferring autonomy and quality to the ego, configuring what is conventionally called the ego psychology. According to Adorno, this egoic autonomy actually exists in developed Western societies, marked by strong individualism and its corresponding hypertrophied consciousness of being herself ${ }^{8}$. Revisionism would thus be descriptively more valid than deep psychology, better suited to the historically affected state of conformation of individualities. This descriptive correction, however, is paid with explanatory poverty by disregarding the dialectical dynamics in the correlation of forces between the core of the individual psyche and the cultural forces and factors. Such conflicts would not only generate, according to Freud, all malaise and suffering in culture, but would also constitute the individual herself as a battlefield always unstable and subject to resounding failures, such as neuroses and psychoses. For Adorno, the loss of an analytical social psychology by neglecting this bet on genealogical factors linked to drives

\footnotetext{
${ }^{7}$ Although Adorno does not cite Freud's text "The drives and their vicissitudes" ["Triebe und Triebschicksale"], he certainly knew it. We believe that the supposed absence of criticism on the internal dynamics of drive formation is due to the disregard of social factors, since Freud describes in detail the aspects inherent to the emergence and mutations of the drives. We shall see later the problematic character of this critique on Freud's supposedly disregard concerning social factors in the formation of the unconscious.
}

${ }^{8}$ Adorno, "Die revidierte Psychoanalise", p.23. All translations in this paper are mine. 
is greater than the descriptive gain of the complex of social factors and their respective networks of reciprocal influence.

One of the great problems of the descriptive dimension of revisionism is the naivety concerning its explanatory power. While Freud employed the genealogical factor of children's experiences to repeat in various forms in later life, Karen Horney dogmatically claims that certain drives and reactions are properly repetitive because they are contradictory, composed of unanswerable tendencies. The worship of an artist, for example, can be the result of an exorbitant ambition - which could in turn be a source of fear itself -, or it may come from a tendency to love an idol because she does not want to do what is necessary to achieve that high place, generating also certain envy (NWP 138). The great problem is that all these forces and tendencies, supposedly used as explanatory principle, do nothing more than to express in other words the problem to be explained. Exorbitant ambition, fear of taking the place of the idolized person, release of concrete attitudes to achieve success, envy etc. are component of the neurotic final state to be explained. It is not immediately clear that each of these tendencies can be admitted as constitutive, natural or "proper" to each of us, according to any model of normality. If an artist's worship needs to be explained, all those other factors that supposedly "explain" it must be explained as well - and to the same extent.

The most relevant reason for Freud to investigate the unconscious instinctual foundations is the experience of suffering, the inalienable mark of the bond between individual and collectivity throughout the history of civilizations. It is not only a matter of a suffering actually experienced, but also inherent in the genesis of the psyche ${ }^{9}$. According to this, Adorno points to a substantive truth of Freud's theory: his insistence on the split of the poles of individuality and universality. More important than this division, however, is the internal division of the subject, torn apart and subjected to unconscious conflicts in its deeper substrates. Quite contrary to this perspective, the revisionists rely on a whole character and personality which, according to Adorno, would only exist in a reconciled society, not imposed on its members through violence, predatory exploitation, perpetuation of hunger, racism, machismo etc. This critique

${ }^{9} \mathrm{Cf}$. Jean Laplanche, “Masochisme et théorie de la séduction généralisé”. In: La révolution copernicienne inachevée. 
follows an Adornian motto of capital importance for the understanding of his work: one does not have to take as reconciled in the scope of the theory what in reality is divided, fractured, submitted to conflicts and so on ${ }^{10}$.

At various times, revisionist positions have clear sense and plausibility (actually, any theory situated in the descriptive plane of multiplicity of factors tends to achieve the appearance of this plausibility). This is true, for example, when Horney rejects a fairly frequent Freudian claim to the correspondence between current events and isolated events in childhood, as if there were an "atomized" link between effect in the present and its past cause. For the revisionist, we must take into account a very important mediation, namely, the whole character. Without the latter, we tend to neglect a large number of current factors that are decisive for the entire symptomatology (NWP 141-4). Adorno puts in suspicion the viability of the concept of wholeness of character, adding that it is not even desirable in a society such as ours, for - we may interpret it would be difficult for an individual with a subjective wholeness to understand the urgency and meaning of the critical intervention in a radically divided, unjust and conflicted world. Besides this criticism, it is necessary to consider the possibility of character structure being referred to singular events. It is not justifiable to disregard, without deeper considerations, that some experiences have greater weight than others in the subjective constitution. That each of these experiences converges to shape a global structure of personality is not simply an unquestionable fact and to be placed just as one of the variables to function as support, since it is in fact a consequence of the processes of reification, the forced harmonization of multiple and conflicted individual experiences. In other words, the unity of the subject taken by the revisionists as support for their theories is not only false but ideological as well. It eschews the strength and vivacity of infantile traumatic experiences through recourse to adverse influences of the environment, conceived in a somewhat vague way, without a critical investigation of its dynamic factors. Instead of the tensions inherent in the fear of castration and the irresolute character of both the Oedipus complex and the original repression, we have the horizontal description of the external bond between individual and family

\footnotetext{
${ }^{10} \mathrm{Cf}$. Deborah Cook, “The sundered totality: Adorno's Freudo-Marxist Paradigm”. In: The culture industry revisited: Adorno on mass culture, pp.1-26.
} 
or society. Again, metapsychological concepts are replaced by abstract general principles lacking in explanation, such as bulimia, which, instead of being referred to the dynamics of repressed infantile experiences, is "explained" through a principle of "general voracity." These critiques apply to Karen Horney's most significant conceptual scheme because she replaces libido with the two principles of striving for security and satisfaction, presented and inserted in the argument as if they did not need to be substantiated.

\section{b. The social dilution of the unconscious}

In their descriptive realism, the revisionists replace the drive dynamics by the influence of the conditions of life to shape the character. Although this approach seems comprehensive and diversified, as we have said, it contains a highly dubious assumption, namely: a more or less rigid division between the ego, conceived as an autonomous entity, and social factors taken as its "influences." This argument is based on an individualist perspective, separating the subject from the social reality in order to delineate the influence received from the latter. Revisionism is therefore pseudo-critical: instead of perceiving the very notion of individuality as social, trying to analyze how profoundly society is reflected in the most intimate mechanisms of repression, it naively takes the ego reality as given and relegates to social conditions the power of causation of neurotic disorders. The result is an externalization of subjective conflicts, and the abstract generality of the concept of "social influences" only duplicates and repeats within the scope of theory what has already been verified in empirical reality. Although useful, this descriptive approach acquires an ideological load, taking as a social fact what should be seen as the effect of perverse mechanisms for deepening divisions and conflicts. Hence the revisionist description ends up contributing to perpetuate these social conditions. Freudian psychoanalysis, on the contrary, insisting on libido as the pre-social foundation of subjectivation, contributes more decisively both to the critical investigation of social rootedness in individuality and to the glimpse of overcoming antagonisms. The sociologization of psychoanalysis removes its more critical and challenging aspect to the status quo, making it acceptable as a theory of the constitution of the 
psyche: "instead of analyzing sublimation, the revisionists sublimate the very analysis." ${ }^{11}$

From this perspective, it is by no means surprising that Horney takes sexuality out of the picture, and more properly the infantile one, as an explanatory parameter of almost all phenomena to be elucidated critically. Where Freud attempted to demonstrate that, despite appearances to the contrary, latent content was sexually, revisionists tended to find more noble, elevated, and culturally acceptable impetus, character traits, and tendencies. This stand perfectly aligns with the principle of scientific objectivity, purging the theoretical discourse of all subjective density, and nothing more prejudicial to this impartiality than sexual desires. Horney insists that affection does not come necessarily from the sublimation or diversion of sexual fantasies, and that sadism arises not always from repressed sexual urges but also from the "weakness, anxiety and revenge impulses" (NWP 59). Instead of an explanatory theory situating the foundation of neurotic phenomena in sexuality, she appeals once again to general concepts from the same plane of the phenomena to be elucidated.

This revisionist conception of sadism is especially important for Adorno because Nazism has dramatically and tragically uncovered how power-longing is not only a "social" phenomenon, but deeply identified with the sexual impulses and their unconscious conflicts. The revisionist tendency is to level the explanatory factors by the conception of a supposedly healthy person. The reason for this lies in the fact that the Freudian genial intuition that sexuality is itself conflicting has not been completely eliminated from the horizon. Moved by the desire to locate the origin of the neuroses in the relation between individual and society, the abstraction of the sexual became a step not only necessary to the internal articulation of the revisionist theory, but also favorable to the acceptance of psychoanalysis as a psychology purified of the obstacle to its acceptance: the sexual content of the unconscious.

As sexuality connects closely to the question of values, this brings us to moral questions. Both Adorno and the revisionists reproach Freud for his ambiguous attitude to this sphere. While critically accusing society of having a repressive sexual morality and deeply investigating the

${ }^{11}$ Adorno, "Die revidierte Psychoanalise", p.28.. 
consequences of the hypertrophied sense of morality ${ }^{12}$, Freud would have left some oppressive principles such as capitalist productivity unquestioned. As far as the revisionists are concerned, Adorno says that, for an inverse reason, they would not be sufficiently critical of established moral standards. Although effectively confronted with all this problematic, critical analysis of foundations of values is set aside, in the same way as the ego itself is not investigated at its source. There is indeed the insistence on the division between typically neurotic concerns, which Karen Horney calls pseudo-moral, and the very ethical ones with which each person is urged to confront and respond in a rationally consistent manner (NWP 10). According to Adorno, this division is arbitrary and unjustified, without specific criteria. - Although, in fact, an objective discourse on this distinction is not possible, it is necessary to take into account that, to a great extent, the hypertrophy of the neurotic moral sense ends up moralizing an infinite number of facets of the real, and the individual does not get a clear awareness of what justify such moral considerations, which tend to be circular, repetitive, acute and without resolution minimally satisfactory throughout all life, even for the person herself ${ }^{13}$.

The social foundation of such neurotic conflicts, for Karen Horney, is the pervasive situation of competition between people and social groups. The continual and desperate effort to assert themselves and defend their interests would be the source of an anguish that leads to disabling neurotic solutions ${ }^{14}$. According to Adorno, the concept of competition is part of an illusory individualistic conception, already invalid to the heyday of liberalism, but that in later capitalism has been frankly replaced by a much more direct bodily threat, less mediated by the subjective consciousness of self-interest. The psychoanalytic categories such as the fear of castration, in this sense, are more faithful to this spirit of direct and intimate confrontation of individuals. Revisionist pluralism, once again, situates on the external relations between individual and society what, for Freud, should be located in a more radical, psychic, unconscious scope. The violence effectively relevant to analytical social psychology is that one internalized by individuals according to a dynamic non-deductible from

\footnotetext{
${ }^{12}$ Cf., for example, Freud, “'Civilized' sexual morality and modern nerve disease”.

${ }^{13}$ Cf. Theodor Reik. Geständniszwang und Strafbedürfnis. Probleme der Psychoanalyse und der Kriminologie.

${ }^{14}$ Karen Horney, The Neurotic Personality of Our Time, p.284.
} 
the socioeconomic categories. Without this properly psychic questioning, psychological inquiry is neutralized in a conception of the world filled with good intentions, but devoid of its substantive critical power.

In the relation between individual and repressive and violent society, the concept of narcissism delineates the phantasy-dimension in which a typical neurotic and desperate solution can be perceived. For both Karen Horney and Adorno, the narcissistic individual suffers from an ego weakness as a result of her confrontation with social forces. For the former, however, there is a loss of contact with ego and its consequent hypertrophy, when the individual compensates for her social impotence with an overvaluation of herself (self-inflation) (NWP 96-7). According to Adorno, the criterion for establishing this excessive value comes from the realm of the same society that generates the frustrations. To the healthy individual Horney attributes all the qualities typically demanded by the capitalist production system, such as initiative, courage, independence and talents. In this sense, the revisionists end up taking advantage of the society against the individual idiosyncrasies, in spite of all discourse against the structures and social forces. Adorno's conception of narcissism presented right after this criticism, however, does not seem very different, for the narcissistic individual would be the one who, faced with the difficulties of finding a more immediate relationship with her fellow men, is forced to direct her libidinal energy to herself ${ }^{15}$. One of the consequences of this introversion of libido might be this self-inflation, but also a selfstiffening capable of generating radical forms of social isolation and inability to communicate. - Although it is not part of the Adornian conceptual complex, it is necessary to keep in mind that affective cathexis does not only designate good or positive emotional aspects, but also destructive ones, in such a way that melancholic depression, for example, is also characterized by a massive investment in the ego, but whose consequence is depreciation, guilt, etc. ${ }^{16}$

\footnotetext{
15 “The Revised Psychoanalysis", p.33. Adorno did not devote himself to delineating precisely his own concept of narcissism, using it in close proximity to Freud's classical formulations. In general, he accepts the idea of a libidinal investment in a weakened ego, emphasizing that such weakening occurs in an atomized society, the origin of the almost annulment of this instance. In the limit, the subject behaves masochistically for not having an ego, and the narcissistic investment becomes paradoxical, because it would lose its object. Cf. Minima Moralia, §40, p.73. There are, however, several other aspects, related to specific arguments, such as those concerning the cultural industry, modern art, moral, etc., whose approach falls outside the scope of this text.
}

${ }^{16}$ Cf. Freud, "Trauer und Melancholie” ["Lute and Melancholy”]. 
The revisionist theories are essentially positive, by systematically rejecting explanatory principles that transcend reality concretely perceived. The Freudian principle of present life being marked by infantile desires, traumas and censures inserts an undesirable negativity in this panorama, for it compels us to construct hypotheses on circumstances without positive and immediate access. It will always be uncertain how far our analytical constructs are capable of overcoming both the analysand's current conscious perspective and the possible interference of the analyst in this reconstruction. Revisionism, in its turn, delineates the ego as the sum of its present constituent elements, as if its comprehension could be satisfactory without a deep insight in its genesis. It results from this conception the perspective of healing as a good management of exchanges between the individual and the environment, through recognition of the conditioning ways of the environment to the individual and the answers of the latter to the former.

\section{c. Freud's utopian pessimism versus Horney's conformist optimism}

As we have said, Adorno agrees with the revisionists' assessment that Freud has an ambiguous and therefore problematic position on the repressive aspect of society. Although Freud criticized inhibitory sexual morality, he allegedly did not questioned the structuring principles of capitalist rationality, and clung to models of normality akin to the same neurotic type of social rules. The Freudian idea of normality as being able to work and to enjoy life [Leistungs- und Genußfähigkeit] is read by Adorno as related to the patterns of productivity, romanticism and happiness typically sold in the consumer society. In this sense, the fact that such a conception converges in the idea of the neurotic individual as unable to measure itself with parameters of socially cultivated morality and ethics is read critically as an index that its author, despite all libertarian discourse, had certain compromise with political, social and economic authoritarianism. (We will critique this position later.)

The solution of the revisionists, however, is seen by Adorno as a worse way. By leveling the deepest unconscious layers to the surface of the "current" impulses, reactions and feelings, they fail to realize how deeply taboos and interdictions are the constitutive element of every desire, implying some form of pleasure in transgression. Because of this leveling, 
Freud's critical conception of every affection as having a sexual root is directly and insistently attacked, what lead us back to a traditional and popular view that sublime tenderness and affection need not "contaminate" with this libidinal root. The consequence is, once again, to subtract psychoanalysis from its critical acuity, becoming a social prescription for the management of impulses whose meaning, voluntarily or involuntarily, is to confirm the same authoritarian standards to be denied by the revision of Freudian theory.

According to Adorno, when differentiating theory and fact description, the first will always contain a moment of falsity, because it distances itself from the positivity of experience, from the actually seen and practiced. This occurs both in the necessary generalizations, placed beyond the complex of particular elements, and in the set of hypotheses anchored in principles, forces and entities that can remain indefinitely without empirical verification. However, according to a programmatic principle of Critical Theory, factual reality is itself false, resulting from complex processes of conformation of the particular elements by the power relations sedimented in the language and the thought in general ${ }^{17}$. Thus, the immediate representation of empirical reality in its theoretical and scientific explanations converges, more often than not, into a duplication of what is false.

The Freudian position, with its insistence on a psychic nucleus with a dynamics non-deductible from historical conditions, carries a pessimism and a negativity more faithful to the state of atomization of the individuals in the societies than the revisionist therapeutic optimism. Although, in Adorno's perspective, Freud has largely neglected how this atomization is the fruit of certain rationality imposed on everything and everyone, such blindness is an indispensable condition for the truth of his theory. The revisionists want, in a hurry, to perceive within the scope of the theoretical explanation itself the humanized dimension of individual and collective relations, while it would be of crucial importance to emphasize the historical-philosophical truth of the alienation of the individual versus the universal.

Notwithstanding this criticism of the revisionists and the defense of the Freudian position, the Adornian perspective gives a somewhat equal

${ }^{17} \mathrm{Cf}$. Max Horkheimer, Traditionelle und kritische Theorie. 
importance to the sociological dimension when considering its relation to the psychic realm. It becomes clear when he says:

In the subsisting constitution of existence, the relations between human beings arise neither from their free wills, nor from their drives, but from social and economic laws, which are imposed upon their heads. If in this existence psychology becomes human or sociable, by acting as if society were that of human beings and determined by its innermost self, then it lends a human glow to an inhuman reality ${ }^{18}$.

I agree with this critical position on the sociable and humanistic optimism of the revisionists. Its argumentative support, however, seems to me inadequate, since the "inhuman" character of society is taken as if it were almost literally nonhuman, coming from wills radically desubjectivated, automated, devoid of any rationality, etc. This argumentative bias may be not sufficiently perceptible in the text we are focusing, but was clearly stated in several passages of the Dialectic of Enlightenment, especially in the second Excursus, "Juliette, or Moral and Enlightenment." This part of the text tried to demonstrate how enlightened morality loses contact with the sentiment and other volitional impulses, becoming so radically reified that it seems to be no longer human. There are countless expressions attesting this argumentative strategy: "Thought becomes totally an organ, it is downgraded to nature" (DA 106) $)^{19}$; "Reason is the organ of calculation, of the plane, it is neutral towards ends, its element is coordination" (DA 107); "It has become the purposeless purpose ... It is the plan considered in itself" (DA 108); "Pure reason became unreason, a procedure without error and without content" (AD 110); "Immersed in the dominant means of production, the enlightenment that strives to undermine the order that has become repressive dissolves itself" (DA 113); "The formalization of reason is merely the expression of the means of machine production. (...) Domination survives as an end in itself, in the form of economic violence" (DA 124); "(...) the non-conscious [bewußtlose] colossus of the real, capitalism devoid of subject [subjektlos], annihilates blindly ...” (DA 134).

\footnotetext{
${ }^{18}$ Adorno, "Die revidierte Psychoanalise", p.36.

${ }^{19}$ All this quotations are from the second Excursus of Dialectic of Enlightenment, and the page numbers refers to the German edition, Dialektik der Aufklärung, listed in the References.
} 
Leaving aside the problem of free will of the earlier quotation from "The Revised Psychoanalysis" - a concept taken as illusory by both psychoanalytical currents and the social philosophy of the Frankfurt School -, we can say that the explanatory principles of human actions must be sought at the confluence of both the drive impulses and of network of linguistic, symbolic, social, political, and other elements, even in the most "inhuman", regressive, barbaric, "cold", abstract, violent society. No matter how "social and economic laws" are actually imposed on every human being, this would not result in anything understandable if there were no desiderative impetus on which such laws are imposed. Adorno's expression that "human relations do not arise from drives" comes, it seems to me, from a generic conception of the drive as an amorphous, multiple, dispersed force, to be shaped indefinitely by culture. ${ }^{20}$ If, however, we conceive the drive as having a logic of its own constitution, according to the laws of structuration of the psyche - such as original and secondary repression, drive and ego formation, Oedipus complex, overcoming of fear of castration -, which are not the direct result of the elements and socio-cultural factors (as Adorno reproves the revisionists), but neither are they deductible from the biological dimension ${ }^{21}$, that phrase of Adorno loses much of its validity.

The philosopher employs the same argumentative strategy in the problem of the new and repetition. Horney blames Freud for advocating a mechanistic conception that all experiences of adult life would be nothing more than repetitions of early childhood events. For her, it matters much more what can be done as different at the present stage from the recognition of the strata underlying the perception of oneself (NWP 41). Her belief in the possibility of the new is clearly optimistic, in contrast to Freud's pessimism and supposed coldness. For Adorno, the compulsion to repetition is the hallmark of every historical stage of civilization to this day, when the mythical forms of assimilation of the world return, under the most varied species, in the rationalized modes of knowledge and action. Thus, analogously to the preceding argument, the supposedly

\footnotetext{
${ }^{20}$ If this hypothesis is correct, Adorno's conception would approximate to that criticized by Michel Foucault: psychoanalysis would confront the social plane to a 'diffuse energism' [énergétisme diffus] of sexual drives. Cf. Histoire de la sexualité. Vol. 1. La volonté de savoir, p.151.

${ }^{21}$ Jean Laplanche has insisted that the drives must be viewed as beyond the natural realm, departing from the instinctual-biological scope; cf. Le fourvoiement de la sexualité chez Freud, specially the second chapter, "Pulsion et instinct".
} 
mechanistic Freudian pessimism would be more faithful to the sociohistorical reality than the complaisant optimism of the revisionists.

The same applies to the affective scope, since the apology of tenderness and love of neighbor is false in relation to how individuals are different from each other, and also false concerning the impossibility of an equalization of affective exchanges. For Horney, every affective bond beyond this measure of reciprocity becomes pathological, while for Adorno, to conceive of love by equivalence only reproduces the principle of capitalist exchange: insistence on inequality and the impossibility of a direct exchange between equals makes more justice to utopia than Horney's voluntarist utopianism.

Adorno brings an aspect of the Freudian conception closer to that of the revisionists, for in a manner analogous to how Horney condemns all love beyond the measure of reciprocity equivalent, Freud takes as childish all passion, without distinguishing "his primary libidinal traits from those produced by repression." ${ }^{22}$ This means that Freud would be also an apologist for socially accepted psychic health principles. The point is that being childish in Freudian theory does not characterize something pathological, objectionable, and then to be cured. The self-infatuation of passion indicates a childish element present in everything beyond the median of human reactions, but at the same time necessary as such. Joy itself only exists because of an excess, whose absence removes all meaning. Moreover, just as Adorno demonstrates in his writings that he does not consider the distinction between repression [Verdrängung] and suppression [Unterdrückung], ${ }^{23}$ he establishes in a non-problematic way a difference between primary and repressed libidinal traits. According to the classical nucleus of Freud's theory, all affective investment has its source in the affections submitted to repression, so that the primary nature referred to by Adorno, unconnected with repression, would lead to a kind of biologism that does not do justice to the idea of repression as "the cornerstone on which the entire edifice of psychoanalysis rests," as Freud says $^{24}$.

\footnotetext{
${ }^{22}$ Adorno, "Die revidierte Psychoanalise", p.39.

${ }^{23}$ About this difference, cf. Jean Laplanche and Jean-Baptiste Pontalis, Vocabulaire de la Psychanalise, entry "Refoulement".

${ }^{24}$ Freud, "Zur Geschichte der psychoanalytischen Bewegung”, p.54.
} 
In the Adornian reading, the division between Freud and the revisionists bears witness to an ambiguity and tension within psychoanalysis as such. The core concept of this criticism is that of adaptation. According to Freud, one of the great problems of neurotic condition is the inability to adapt to social conditions, requirements and norms ${ }^{25}$ Adorno interprets this idea as an apology for the status quo, a resignation to what society already establishes as correct, valid, useful, and so on. The example for this is the interdiction Freud devised for the analyst in yielding to the erotic desires of a patient: the psychoanalyst should refuse this demand for a love acceptable both psychologically and socially, though uncertain as to its fulfillment in the future ${ }^{26}$. While Freud, however, insists on the unresolved duality between the drive impulses and the demands of society, the revisionists seek to flatten this polarity through well-intentioned precepts. In both cases, the ideal of adaptation is placed as the mainspring of treatment, but with the difference that in Freud the structural imbalance between individual and society is still expressed in the theory itself, what makes it more realistic.

Although this theme is quite complex and deserves a reflection of its own, we can say that the principle of adaptation of Freud does not simply mean a resigned conformation to what is established by society, nor is the end of the psychic treatment. If this were to be the case, psychoanalysis would consist of a device of depersonalization, producing a mass society, the same one the author acidly criticized in his text "Group Psychology and Ego Analysis". The neurotic individual is one who falls short of adapting to reality, whereas psychic health means going beyond adaptation: "Later, the ego learns that there is another way to assure satisfaction besides the described adaptation to the outside world. It is also possible to intervene in the outside world and purposely create in it the conditions that make the satisfaction possible." ${ }^{27}$

\footnotetext{
${ }^{25}$ Sometimes this idea is used by Freud in relation to sexual objects: "The illness of frustration is also seen from the point of view of the inability to adapt to the reality, namely to the one case that the reality denies the satisfaction of the libido", "Über neurotische Erkrankungstypen" ["On neurotic disease types"], p. 326, but also concerning wider scopes: "There is an adaptation to the alien-to-ego [ichfremde] piece of the inner world, piece which is represented by the symptom, so as the ego normally brings that adaptation against the real external world", "Hemmung, Symptom und Angst" ["Inhibition, Symptom and Anxiety"], p.126.

${ }^{26}$ Freud, "Bemerkungen über Übertragungsliebe” [“Observations on Transference Love”], p.319.

27 “Die Frage der Laienanalyse,” [“The Question of Lay Analysis”], p.228.
} 
The neurotic loss of the capacity to work and enjoy life [Leistungsund Genußfähigkeit] conceived of by Freud does not imply the psychic health as accepting the principles of capitalist production, models of romantic love and happiness in the consumer society. The freedom of judgment, refusal or acceptance of what is established in the collective sphere is the main point. That one, for example, can not manage her time, spending much of his days with useless amusements and activities without professional or personal benefit, that is a neurotic condition whose overcoming does not simply mean that all wasted time must obey now the capitalist system of production. This individual lacks a robust sense of relative evaluation of work, play, rest, social life, etc. The psychoanalytic objective is, therefore, to promote the attainment of a sufficient freedom of evaluation of its own impulses and principles, in close connection with the whole social sphere. - With regard to the example of transference love, it is clear that the affective demand of the patient does not occur under the aegis of a subjectively free evaluation, because the analytical space places the analysand under the impact of his unconscious investments. By virtue of the fundamental rule of psychoanalysis of a frank opening of the analysand, the analyst is given a role and a meaning disproportionate to those of empirical social life. Thus it is necessary to replace this experience of the principle of pleasure for that of reality, which does not mean to negate the importance of love, but rather to place it in a more enlightened perspective, less indebted to unconscious impulses and fantasies.

\section{Conclusion}

Considering the two aspects of Adorno's reading of psychoanalysis, namely the appropriation of themes and concepts for the construction of his philosophy and the critical approach of psychoanalytic theory, we consider the first quite profitable, bringing to the psychoanalysis interesting elements of cultural analysis, such as the interpretation of the Odyssey, the critique of mass culture, the reading of Kafka's work, the analysis of the origins of anti-Semitism, and so on. The second, however, seems to us inadequate in several respects, by neglecting to a great extent the specificity of the unconscious nucleus of psychic subjectivity. The text analyzed by us is instructive on this topic, for Adorno makes this criticism 
to the revisionists, but ends up presenting the same misunderstanding when presenting his own criticisms to the founder of psychoanalysis.

In an important text on this subject, the aphorism 38 of Minima Moralia, Adorno criticizes Freud emphatically for conceiving one of the objectives of psychoanalysis as the return to the neurotic patient the “capacity for enjoyment” [Genußfähigkeit]:

As if the mere expression "capacity for enjoyment" was not enough to reduce this same capacity to the extreme, should something like this exist. ${ }^{28}$ As if happiness, obtained through speculation about happiness, were not the opposite of happiness, were no longer an invasion of modes of behavior planned institutionally in the context of the increasingly reduced experience. What state the dominant consciousness must have reached to raise, with stubborn seriousness, the determined proclamation of consumption addiction and the enjoyment of champagne, as it was reserved for the attachés in the Hungarian operettas, to a maxim of the correct life. ${ }^{29}$

There is no doubt that if an analyst conducts psychoanalytic treatment keeping in mind that neurotic unhappiness has its more favorable overcoming in the uncontrolled enjoyment of consumer goods and frivolous pleasures, we are facing an attack on a psychic health worthy the name. This possibility, however, constitutes the worst reading of the Freudian idea. One component of the shortage of neurotic life is the inability to obtain any satisfaction - among which paradigmatically the experience of orgasm and sexual pleasure -, to which are added: an exaggerated pessimism, the perception of the life being wasted, constant censorship and self-punishment, and a host of other depressive and melancholic aspects that make existence unjustified. The role of analysis, however, is not to propagate adherence to socially shared precepts of happiness and easy pleasures, but to remove the person from this true psychic and emotional quagmire, a monstrous obstacle to the pleasures recognized by any sensible human being as necessary, indispensable. Adorno's critical doubt about the mere existence of a "capacity for

\footnotetext{
${ }^{28}$ Commenting on this passage, Christine Kirchhoff says: "This is undoubtedly true. For the expression 'capacity for enjoyment' does not sound exactly as if all pleasure were expunged? - as if it were rather to designate the opposite of enjoyment, and not the ability to surrender to something?" ("Übertreibungen. Adornos Kritik psychoanalytischer Theorie und Praxis", p.6o.)

${ }^{29}$ Adorno, Minima Moralia, p.69.
} 
enjoyment" becomes absurd when addressed to impotent men or to frigid women. Only regrettable oblivion or an unbelievable lack of empathy leads to overlooking the fact that millions of people have an insurmountable difficulty in obtaining pleasures and satisfactions crucial to existence. Unlike Christine Kirchhoff, we take the capacity for enjoyment as a notion that precisely designates the subjective impossibility of surrendering to a thing or person. A woman suffering from vaginismus has precisely this barrier: she can not, however much she tries, to indulge in sexual intercourse. How can the "capacity for enjoyment" in this case mean the opposite of the experience of a pleasurable penetration?

Although this theme is also difficult and worthy of more in-depth reflections, these notes seem sufficient to delineate the short-circuit between the social-sociological dimension and the psycho-subjective interiority practiced by Adorno. Instead of realizing how much neurosis demonstrates an unconscious logic to be understood in itself to give rise, at the end of the therapeutic process, to a freedom of individually chosen actions, the philosopher already associates directly and immediately the exit from the neurotic imprisonment to blind and naive adherence to social norms of well-being. Thus, Adorno ends up practicing, in his own way, what he denounced in the Freudian revisionists: a hasty sociologization of psychoanalysis.

\section{References}

ADORNO, Theodor Wiesengrund. "Die revidierte Psychoanalyse". In: Soziologische Schriften. Gesammelte Schriften. Vol.8. Frankfurt am Main: Suhrkamp, 1997, p.20-41.

ADORNO, Theodor Wiesengrund. Minima moralia. In: Gesammelte Schriften, vol.4. Frankfurt am Main: Suhrkamp, 1997.

ADORNO, Theodor Wiesengrund. "Zur Bekämpfung des Antisemitismus heute". Gesammelte Schriften, vol.2o. Frankfurt am Main: Suhrkamp, 1997, p.36o-83.

ADORNO, Theodor Wiesengrund \& HORKHEIMER, Max. Dialektik der Aufklärung. In: ADORNO, Theodor Wiesengrund. Gesammelte Schriften. Vol.3. Frankfurt am Main: Suhrkamp, 1997.

DAHMER, Helmut. “Adorno's view of psychoanalysis”. Thesis Eleven, 2012, pp.97-111. 
FOUCAULT, Michel. Histoire de la sexualité. Vol. 1. La volonté de savoir. Paris: Gallimard, 1976.

FREUD, Sigmund. “Bemerkungen über Übertragungsliebe”. In: Gesammelte Werke, vol. X. Frankfurt am Main: Fischer, 1999, pp.305-323.

FREUD, Sigmund. "Die Frage der Laienanalyse". In: Gesammelte Schriften, vol. XIV. Frankfurt am Main: Fischer, 1999, pp.207-95.

FREUD, Sigmund. "Hemmung, Symptom und Angst”. In: Gesammelte Schriften, vol.XIV. Frankfurt am Main: Fischer, 1999, pp.111-205.

FREUD, Sigmund. “Trauer und Melancholie”. In: Gesammelte Schriften, vol.X. Frankfurt am Main: Fischer, 1999, pp.427-46.

FREUD, Sigmund. “Triebe und Triebschicksale”. In: Gesammelte Schriften, vol.X. Frankfurt am Main: Fischer, 1999, pp. 209-232.

FREUD, Sigmund. "Über neurotische Erkrankungstypen”. In: Gesammelte Schriften, vol.VIII. Frankfurt am Main: Fischer, 1999, pp.321-29.

FREUD, Sigmund. “Zur Geschichte der psychoanalytischen Bewegung”. In: Gesammelte Werke, vol. X. Frankfurt am Main: Fischer, 1999, pp.43-114.

HORKHEIMER, Max. Traditionelle und kritische Theorie. Berlin: Fischer Taschenbuch, 1992.

HORNEY, Karen. New Ways in Psychoanalysis. Londres: Butler \& Tanner, 1947

HORNEY, Karen. The Neurotic Personality of Our Time. New York: W.W. Norton \& Company, 1937.

KIRCHHOFF, Christine. "Übertreibungen. Adornos Kritik psychoanalytischer Theorie und Praxis”. In: DECKER, Oliver \& TÜRCKE, Christoph (Orgs.). Kritische Theorie Psychoanalytische Praxis. Gießen: Psychosozial-Verlag, 2007, pp.59-73.

KLEIN, Richard. "Gemischte Gefühle. Adomo, die kritische Theorie und die psychoanalytische Praxis”. In: DECKER, Oliver \& TÜRCKE, Christoph (Orgs.). Kritische Theorie - Psychoanalytische Praxis. Gießen: Psychosozial-Verlag, 2007, pp.74-102.

LAPLANCHE, Jean \& PONTALIS, Jean-Baptiste. Vocabulaire de la Psychanalise. Presses Universitaires de France, 1967.

LAPLANCHE, Jean. Le fourvoiement de la sexualité chez Freud. Paris: Synthélabo, 1999. 
800 | Veritas | Porto Alegre, v. 63, n. 2, maio-ago. 2018, p. 780-80o

LAPLANCHE, Jean. Jean Laplanche, "Masochisme et théorie de la séduction généralisé”. In: La révolution copernicienne inachevée. Paris: Aubier, 1992.

RANTIS, Konstantino. Psychoanalyse und 'Dialektik der Aufklärung'. Lüneburg: zu Klampen, 2001.

REIK, Theodor. Geständniszwang und Strafbedürfnis. Probleme der Psychoanalyse und der Kriminologie. Leipzig: Internationaler Psychoanalytischer Verlag, 1925.

SCHILLER, Hans-Ernst. Freud-Kritik von links. Bloch, Fromm, Adorno, Horkheimer, Marcuse. Hamburg: zu Klampen, 2017.

\section{Endereço Postal:}

Departamento de Filosofia UFMG

Av. Pres. Antônio Carlos, 6627 -Belo Horizonte - MG, Brasil

Data de recebimento: 30/05/2018

Data de aceite: $17 / 09 / 2018$ 